Recent Aotearoa/New Zealand Social Science Books (2019-2020)

\title{
Charles Crothers
}

Auckland University of Technology, Auckland, New Zealand

\section{Abstract}

A listing of social science New Zealand-related books published between 2019 and early 2021 is provided.

Key words: New Zealand; Social sciences, books, reviews, publishers.

Cite as: Crothers, C. (2021). Recent Aotearoa/New Zealand Social Science Books (2019-2020). Aotearoa New Zealand Journal of Social Issues, vol 1. URL: https://ojs.aut.ac.nz/anzjsi/article/view/6 
Over the last two years at least some 75 social science books related to New Zealand were published. Given how central books and their reviews are to the development of any social research community it is important to endeavour to track both and make their availability more visible. This note provides a listing of these titles, together with a brief aggregate description and a discussion of methods for finding these books. For similar earlier reports see Crothers (2008 and 2015) with Crothers (2015) attempting to rate 'popularity' of New Zealand sociology books.

This task is not straightforward. Larger New Zealand libraries (and especially University Libraries) cover much of the target 'population' of books but their catalogues are not always optimised to provide searches which cover the parameters of New Zealand across the social sciences subject-matter and for a specified time-period, and which also allow ready-usable retrieval of the information. Worldcat is a useful supplement which lies behind several other catalogues, and the National Library catalogue can also be helpful, especially 'Publications in New Zealand'. Perhaps the most comprehensive sources is the downloadable excel-format monthly reports of new records added to Publications New Zealand should include relevant title and certainly includes many reports issued by organisations. Since these include Dewey numbers and subject-terms disciplinary relevance can be identified, although relevance to NZ may be more difficult to judge. Publications New Zealand includes many reports issued by organisations, many of which are better classified as reports than books and so are not recorded in this note. ("Publications New Zealand is New Zealand's National Bibliography. It contains descriptions of books, periodicals, films, music and other material published in New Zealand, or with a significant New Zealand content").

Beyond these recourse can be made to the websites of relevant publishers. New Zealand publishers of social science are mainly confined to the University Presses (although these are more interested in novels, poetry and history), Dunmore, Huia and the NZCER Press. Lists of publishers are available at https://authors.org.nz/publishers/ and https://publishers.org.nz/members/and Appendix 1 contains information on the main ones which are relevant. Book-sellers websites can also be relevant, although often key information is not readily presented: a leading example is https://www.fishpond.co.nz/.

Developing an operational categorisation of social sciences is problematic. While 'social sciences' is a valid academic category comprising several disciplines and an array of 'studies', it is less readily translatable in library catalogue terms, although subject-terms and classification codes help enormously if these are readily available in the source being used. Books vary enormously too in terms of sophistication, or audience, and it is not always easy to separate out more seriously scholarly studies from others: indeed, a wide range needs to be covered including interview material, biographies, and wider commentary and interpretations. Whether or not any item should be included in the below listing might depend on examination of each actual book. 
The following compilation was sourced from the AUT library catalogue using filters 'New Zealand' and 'books/ebooks' for the last 2 years and for the 'Social' category. This means that the listing is dependent on processes in this library. The search category provided includes subcategories such as 'social conditions', 'social aspects' etc. Where available, information about the book could be as uploaded from the catalogue, usually scrapped from publisher's websites. To the extent possible with limited information the material was scanned to include those well-grounded in social science theories, literature and methods, while excluding textbooks and also 'professional' material. Boundaries with law, history, humanities and even sciences are blurry but I've erred on the side of caution. (Although erring towards presentism, only more recent history is covered since published attention to the New Zealand past is voluminous and of varying quality (at least a hundred history titles are published annually in New Zealand. There is a special handling for the history of social sciences where all relevant material is included. Again, what is relevant to New Zealand can be debatable and I was mainly guided by the inclusion of the country name in titles/subtitles. The entries are presented in order of alphabet of title. Some are both books and e-books but format may vary according to the access available to any reader and so this is not recorded.

The time-span of 2019-2021 for date of publication should not be too problematic, although some sources provide different dates. Reissues (especially) or subsequent editions can be difficult when they are not - as sometimes happens - clearly identified. (Moreover, publishers and other websites seem often loath to provide clearly visible information on publication dates.)

Many cross-national books (also Handbooks, Encyclopedia etc.) include a New Zealand chapter or several, but these can be hard to find, and are not included. Comparative study titles including New Zealand are included.

Some 75 books were identified over this period, mainly published in 2019. Local publishers predominate but many of these are quite small presses and many books are published by overseas publishers (notably Routledge, Springer). Some two dozen books are overseas published and a similar number are edited. Occasional important books are published by overseas publishers who are rare publishers of New Zealand material, and these can be difficult to identify. Some predatory publishers might produce books within the parameters of this note, although none surfaced for this period.

The material includes some major studies: e.g. Spoonley; Greenback on refugees' narratives, Nissen on the politics of students, Park et al. longitudinal ethnography on people with haemophilia, Schubert-Mcarthur's ethnography of Te Papa, Vowles and Curtin on the 2017 election, Wang on Chinese international students and Zhang on Chinese migrants. Perhaps surprisingly for what might seem a quite particular topic, two books cover sex workers.

Some are collections of case-studies or collections of individual interviews presented without much further interpretative commentary. Some report the experience of NZ scholars (e.g. Corballis, Jones, Middleton \& May, Phillips, Ruru \& Nikora). A few history titles arte included here such as Lineham's study of the Auckland city mission. The final item in the listing is an Atlas (MacDowell). Other books, often richly illustrated, present 
assemblages of artefacts (e.g. Brickell \& Collard). Another development is that some items are completely in Te Reo while others include portions.

Finally, book reviews are important in not just notifying audiences of books but beginning their description and assessment, but of course the lag in their being written and published reviews are not yet of much help in relation to recent publications. And of course reviews published in NZ journals are by no means confined to NZ books, just as some NZ books are reviewed in overseas journals. I attempted to search for relevant reviews using Index NZ (INNZ) without too much success as it shows social science journals published negligible reviews over this period. Most of those recorded are published in the Journal of New Zealand Studies or Journal of Pacific History. A rare example of that most useful genre of review essays is Dalziel (2020). For an analysis of the NZ system of journals see Crothers, 2017.

In conclusion, the stream of book-format contributions continues at a considerable rate. There may be a limited market for longer books which are serious contributions to the scholarship of NZ studies, but clearly some are indeed published, especially by overseas academically-orientated publishers. These are supplemented by local publishers and both streams produce a wide array of relevant materials. Some interesting book titles have been thrown up in this search, but this has been somewhat counterbalanced by possible gaps (either in publishing or in my searching of titles) across several disciplinary areas.

\section{References}

Crothers, C. (2017) The NZ Social Science Journal System: characteristics and visibility. New Zealand Library and Information Management Journal, 56(2), 23-31. https://10.6084/m9.figshare.5715055

Crothers, C. (2015). Recent (2015) Sociology-Relevant Books About New Zealand. . New Zealand Sociology, 30(4), 280-288.

Crothers, C. H. (2012). Most influential sociological materials on New Zealand: An editorial reporting bibliometric voting. New Zealand Sociology, 27(1), 4-12.

Crothers, C. (2008). Recent (2005-2008) social science-relevant books on New Zealand. New Zealand Sociology, 23(1), 99-112.

Dalziel, Paul (2020) New Zealand books on wellbeing: a review essay New Zealand books on wellbeing: a review essay. Kotuitui https://doi.org/10.1080/1177083X.2020.1745248

\section{Appendix 1: List of New Zealand Publishers of Social Sciences}

Auckland University Press: Publishes creative and scholarly work of interest to a general readership. Produces about 30 titles a year with a focus on NZ history, Maori and Pacific studies, art, poetry, popular science and business.

Awa Press: An independent NZ owned company specialising in contemporary non-fiction by New Zealand and overseas authors. 
Bridget Williams Books Ltd: An independent publisher focusing on NZ history, Maori experience, contemporary issues and woman's studies.

Canterbury University Press: An academic press publishing non-fiction works for the academic and general markets.

Cape Catley Ltd: A small independent publishing house with interest in NZ fiction, children's books, social justice, feminism, politics, local history, biography and autobiography, health, gardening and yachting.

Cengage Learning New Zealand: provider of learning solutions to the secondary school and higher education markets. Committed to publishing the finest educational resources for students and teachers.

Craig Potton Publishing Ltd: Specialises in quality non-fiction, with a particular interest in photography, natural history, outdoor recreation, reference, biography.

David Bateman Ltd: Publisher of non-fiction for both local and overseas readers including books on food, lifestyle, craft, health, sport, history, environment, natural history, Maori, Pasifika, art and culture.

Dunmore Publishing: Publishes 15-20 broad-ranging non-fiction titles each year, covering health, economics, politics, society, education and history.

Huia Publishers: Publishes Maori and Pacific writers and promotes the Maori language.

Massey University Press: Massey University Press was launched by Massey University in 2015. It publishes scholarly works by both the university's top researchers and non-Massey authors alike, across a range of topic areas.

Ngaio Press: Boutique publisher specialising in quality books about NZ and New Zealanders.

NZCER Press: NZCER is at the leading edge of educational thinking, both nationally and internationally, publishing books for early childhood, primary, secondary and tertiary teachers, as well as publishing educational research aimed at the academic market.

Otago University Press: Publishes about 20 scholarly works and books for general readers each year. Special emphasis is given to original research in history, the arts, natural history and social and health sciences.

Penguin Random House (NZ): A division of Pearson, Penguin Group (NZ) produces about 80-100 new books a year under the Penguin, Viking, Raupo and Puffin imprints. These cover a very wide subject range, from literary fiction, history and biography to lifestyle, cookery and children's books.

Potton \& Burton: The company specialises in quality non-fiction, with an emphasis on high standards of production and a particular interest in photography, natural history, outdoor 
recreation, reference, biography, New Zealand art and culture, and social and environmental issues.

Steele Roberts Publishing: Publishes quality literature and non-fiction. Includes art and poetry, business, Maori, children's, humour, self-help, current affairs and general books.

Te Papa Press: Publishing imprint of the Museum of NZ Te Papa Tongarewa. Publishes a wide range of catalogues, museum books and scholarly research titles based on collections and exhibitions as well as illustrated contemporary and historical art books.

Victoria University Press: Major scholarly publisher specialising in New Zealand history and public affairs and fiction and poetry.

\section{Appendix 2: Listing of 2019-2021 Social Sciences Books relevant to New Zealand}

$100 \%$ pure future: New Zealand tourism renewed.

Editor: Bennett, Sarah

Published: Wellington: Bridget Williams Books Ltd, 2020.

Adventures of a psychologist: reflections on what made up the mind.

Author: Corballis, Michael

Published: London; New York: Routledge, Taylor \& Francis Group, 2021.

Advising governments in the Westminster tradition: policy advisory systems in Australia, Britain, Canada and New Zealand

Authors: Jonathan Craft; J Halligan

Published: Cambridge : Cambridge University Press, 2020.

Agency of Hope: the story of the Auckland City Mission, 1920-2020.

Author: Peter Lineham

Published: Auckland: Massey University Press, 2020.

Alcohol: a dangerous love affair: an in-depth study of the effects of alcohol on users, the community, the nation of New Zealand, and globally

Authors: G A F Seber; Graeme Woodfield; G W R Palmer

Published: Ruawai, New Zealand : G. Seber : Wild Side Publishing, 2020.

Ambition: What New Zealanders Think and Why It Matters

Authors: Fry, Julie and Glass Hayden

Published: AmbitionNZ, 2019.

Aotearoa New Zealand in the global theatre marketplace: travelling theatre.

Author: Wenley, James

Published: London; New York, New York: Routledge, 2021.

Te aotūroa tātaki: inclusive early childhood education: perspectives on inclusion, social justice and equity from Aotearoa New Zealand. 
Editors: Gunn, Alexandra C.; Surtees, Nicola; Gordon-Burns, Diane; Purdue, Kerry Published: Wellington: NZCER Press, 2020.

Beyond these shores: Aotearoa and the world.

Editor: Hall, Nina

Published: Wellington: Bridget Williams Books, 2020.

Biculturalism at New Zealand's National Museum: An Ethnology of Te Papa

Author: Schubert-Mcarthur Tania

Published: Routledge, 2019.

A careful revolution: towards a low-emissions future.

Editor: Hall, David

Published: Wellington: Bridget Williams Books, 2019.

Chinese international students and citizenship: a case study in New Zealand.

Author: Zhang, Xiudi

Published: Singapore: Springer, 2020.

Crisis and disaster in Japan and New Zealand: actors, victims and ramifications.

Editors: Bouterey, Susan; Marceau, Lawrence Edward

Published: Singapore: Palgrave Macmillan, 2019.

Democratic policies and practices in early childhood education: an Aotearoa New Zealand case study.

Author: Mitchell, Linda

Published: Singapore: Springer, 2019.

Discursive navigation of employable identities in the narratives of former refugees.

Author: Greenbank, Emily

Published: Amsterdam, Philadelphia: John Benjamins Publishing Company, 2020.

Doing Islam, Being Muslim Narratives of Muslim Women \& Physical Activity in New Zealand Author: Nargis, Ali

Published: Saarbrul̀cken LAP LAMBERT Academic Publishing, 2019.

For women and children: a tribute to Geraldine McDonald.

Editors: Middleton, Sue, \& May, Helen

Published: Wellington NZCER Press 2019

Free to Be Children: Preventing child sexual abuse in Aotearoa New Zealand.

Author: Salisbury, Robyn.

Published: Chicago: Massey University Press, 2020.

Fuelling dissension: coal and coal mining in 21st century New Zealand.

Author: Young, Jane

Published: Owaka: Triple Helix Resources Ltd, 2019. 
Gangland: New Zealand's underworld of organised crime

Author: Savage, Jared

Published: Auckland: HarperCollins Publishers, 2020.

Governing Social Protection in the Long Term: Social Policy and Employment Relations in Australia and New Zealand

Author: Ramia, Gaby

Published: Switzerland: Springer, 2020.

Haemophilia in Aotearoa New Zealand: more than a bleeding nuisance.

Authors: Park, Julie et al.

Published: London; New York: Routledge, Taylor \& Francis Group, 2019.

Heartland strong: how rural New Zealand can change and thrive.

Editor: Brown, Margaret; Kaye-Blake, Bill; Payne, Penny

Published: Auckland, Zealand: Massey University Press, 2019.

Higher education for sustainability: seeking intellectual independence in Aotearoa New Zealand.

Author: Shephard, Kerry

Published: Singapore: Springer, 2020.

Imagining decolonisation.

Author: Kiddle, Rebecca et al.

Published: Wellington: Bridget Williams Books Ltd, 2020.

Improving Buildings, Cutting Carbon

Editors: Libby Grant, Helen Viggers \& Philippa Howden-Chapman

Published: Otago University Press, 2021.

Indigenous pacific approaches to climate change.

Authors: Carter, Lyn

Published: Cham, Switzerland: Palgrave Macmillan, 2019.

Indigenous peoples and the state: international perspectives on the Treaty of Waitangi. Authors: Hickford, Mark; Jones, Carwyn

Published: Abingdon, Oxon, England; New York, New York: Routledge, 2019.

Intersections of inequality, migration and diversification: the politics of mobility in Aotearoa/New Zealand.

Editors: Simon-Kumar, Rachel; Collins, Francis L., Friesen, Wardlow

Published: Cham, Switzerland: Palgrave Macmillan, 2020.

Jobs, robots \& us: why the future of work in New Zealand is in our hands.

Author: Salmon, Kinley 
Published: Wellington: Bridget Williams Books, 2019.

Justice \& Race 2020: campaigns against racism and abuse in Aotearoa New Zealand Author: Oliver Sutherland

Published: Wellington: Steele Roberts, 2020.

Living with the climate crisis: voices from Aotearoa.

Editor: Doig, Tom

Published: Wellington: Bridget Williams Books, 2020.

Making history: a New Zealand story.

Author: Phillips, Jock

Published: Auckland: Auckland University Press, 2019.

Making a difference in families: research that creates change

Authors: Jackie Sanders; Robyn Munford

Published: Abingdon, Oxon ; New York, NY : Routledge, Taylor \& Francis Group, 2020.

Matamua ko te kupu!: te haka tena! te wana, taku ihi, e, pupuritia!.

Authors: Kāretu, T. S.

Published: Tamaki Makaurau, Aotearoa: Auckland University Press, 2020.

Migrant and diasporic film and filmmaking in New Zealand.

Editor: Zalipour, Arezou

Published: Singapore: Springer, 2019.

My body, my business: New Zealand sex workers in an era of change.

Author: Wilton, Caren

Published: Dunedin: Otago, 2019.

Nature and wellbeing in Aotearoa New Zealand: exploring the connection.

Author: Knight, Catherine

Published: Ashhurst: Totara Press, 2020.

New Chinese migrants in New Zealand: becoming cosmopolitan? roots, emotions, and everyday diversity.

Author: Wang, Bingyu

Published: London; New York: Routledge, Taylor \& Francis Group, 2019.

The new New Zealand: facing demographic disruption.

Author: Spoonley, Paul

Published: Auckland: Massey University Press, 2020.

The New New Zealand: The Maori and Pakeha Populations

Author: Moneyhun, William

Published: McFarland, 2020. 
Ngā kete mātauranga: Māori scholars at the research interface.

Editors: Ruru, Jacinta; Nikora, Linda Waimarie

Published: Dunedin: Otago University Press, 2021.

Not in narrow seas: The Economic History of Aotearoa New Zealand

Author: Easton, Brian

Published: Auckland: Auckland University Press, 2020.

This Pākehā life: an unsettled memoir.

Author: Jones, Alison

Published: Wellington: Bridget Williams Books, 2020.

Past caring?: women, work and emotion.

Editors: Brookes, Barbara L. ; McCabe, Jane; Wanhalla, Angela,

Published: Dunedin: Otago University Press, 2019.

Political identity in discourse: the voices of New Zealand voters.

Author: Woodhams, Jay M.

Published: Cham, Switzerland: Palgrave Macmillan, 2019.

Politics in the playground: the world of early childhood in Aotearoa New Zealand.

Author: May, Helen

Published: Dunedin: Otago University Press, 2019. Third ed.

A populist exception?: the 2017 New Zealand general election.

Editors: Vowles, Jack; Curtin, Jennifer

Published: Acton, Australian Capital Territory: Australian National University Press, 2020.

The promise and practice of university teacher education: insights from Aotearoa New Zealand. Authors: Gunn, Alexandra et al.

Published: London, England: Bloomsbury Academic, 2021.

Promises, promises: 80 years of wooing New Zealand voters.

Authors: Robinson, Claire

Published: Auckland: Massey University Press, 2019.

Protest Tautohetohe: objects of resistance, persistence and defiance.

Authors: Gibson, Stephanie; Williams, Matariki; Cairns, Puawai

Published: Wellington: Te Papa Press, 2019.

Public knowledge.

Editor: Johnson, Emma

Published: Christchurch: Freerange Press, 2019.

Public sector accounting, governance and accountability: experiences from Australia and New Zealand.

Editors: Pilcher, Robyn; Gilchrist, David 
Published: London; New York: Routledge, Taylor \& Francis Group, 2019.

Queer Objects

Authors: Brickell Chris; Collard Judith

Published: Dunedin: Otago University Press, 2019.

Rangahau: research at Massey University

Author: Anna Dickson

Published: Auckland: Massey University Press, 2020.

Rebuilding the kāinga: lessons from te ao hurihuri.

Author: Kake, Jade

Published: Wellington: Bridget Williams Books Ltd, 2019.

Reclaiming indigenous governance: reflections and insights from Australia, Canada, New Zealand, and the United States

Editors: William Nikolakis, Stephen Cornell, Harry W. Nelson.

Published: Arizona: The University of Arizona Press, 2019.

Redefining citizenship in Australia, Canada, and Aotearoa New Zealand.

Author: Mann, Jatinder

Published: New York, New York: Peter Lang, 2019.

Reflections: on the work of the New Zealand National Commission for UNESCO.

Author: Tait, Edna

Published: Wellington: NZCER Press, 2019.

Religious education and the anglo-world: the impact of empire, britishness, and decolonisation in Australia, Canada, and New Zealand.

Author: Jackson, Stephen

Published: Leiden, The Netherlands; Boston: Brill, 2020.

Rethinking oral history and tradition: an indigenous perspective.

Author: Mahuika, Nēpi

Published: New York, New York: Oxford University Press, 2019.

Rottenomics: the story of New Zealand's leaky buildings disaster.

Author: Dyer, Peter

Published: Auckland: David Bateman, 2019.

A seat at the table: New Zealand and the United Nations Security Council, 2015-2016.

Editors: Hassall, Graham; Partow, Negar

Published: Auckland: Massey University Press, 2020.

Sex work and the New Zealand model: decriminalisation and social change.

Editors: Armstrong, Lynzi; Abel, Gillian

Published: Bristol, England: Bristol University Press, 2020. 
Shouting zeros and ones: digital technology, ethics and policy in New Zealand.

Editor: Chen, Andrew

Published: Wellington: Bridget Williams Books, 2020.

Simulating societal change: counterfactual modelling for social and policy inquiry.

Authors: Davis, Peter; Lay-Yee, Roy

Published: Cham, Switzerland: Springer, 2019.

Small states and the changing global order: New Zealand faces the future.

Editor: Brady, Anne-Marie

Published: Cham, Switzerland: Springer, 2019.

Social Policy Practice and Processes in Aotearoa New Zealand

Editors: Graham Hassall and Girol Karacaoglu

Published: Auckland: Massey University Press, 2021.

STEM education in primary classrooms: unravelling contemporary approaches in Australia and New Zealand.

Editors: Fitzgerald, Angela; Haeusler, Carole; Pfeiffer, Linda

Published: London; New York, New York: Routledge, 2020.

Student political action in New Zealand.

Author: Nissen, Sylvia

Published: Wellington: Bridget Williams Books, 2019.

Successful public policy: lessons from Australia and New Zealand.

Editors: Luetjens, Joannah; Mintrom, Michael; Hart, Paul 'T.

Published: Acton, ACT: ANU Press, 2019.

From suffrage to a seat in the house: the path to parliament for New Zealand women Author: Jenny Coleman

Published: Dunedin: Otago University Press, 2020.

The survival of Māori as a people: a collection of papers by Emeritus Professor Whatarangi Winiata

Author: Winiata, Whatarangi

Published: Aotearoa Books, 2021.

Te Kai a te Rangatira: leadership from the Māori world.

Editors: Tapiata, Rawiri J., Smith, Renee; Akuhata-Brown, Marcus

Published: Wellington: Rawiri J. Tapiata, Renee Smith \& Marcus Akuhata-Brown with Bridget

Williams Books Ltd, 2020.

The terror attacks in Christchurch/New Zealand and Sri Lanka in 2019 a socio-economic cost-benefit analysis 
Authors: Helmut Maier; Enze Wang

Published: Berlin Leontief-Institut fur Wirtschaftsanalyse, 2019.

Transforming the welfare state: towards a new social contract.

Author: Boston, Jonathan

Published: Wellington: Bridget Williams Books, 2019.

Tribal economies - Ngāi Tahu: an examination of the historic and current tītī and pounamu economic frameworks

Authors: Rout, Matthew ${ }_{L}$ and John Reid

Published: Ngai Tahu Research Centre, 2019.

We are here: an atlas of Aotearoa.

Authors: McDowall, Chris \& Tim Denee

Published: Auckland: Massey University Press, 2019. 